\title{
Fungi in Surtsey soils - abstract
}

\section{Elisabet Henriksson and Lars Eric Henriksson}

\author{
Department of Physiological Botany, Uppsala University, Box 540, S-751 21 \\ Uppsala, Sweden
}

The volcanic island of Surtsey in the Westmann Islands, Iceland, was formed by a series of submarine eruptions from 1963 to 1967. It is a natural area, giving scientists the opportunity to study the biological succession without interference from man. In 1972, the occurrence of micro-fungi in soil samples gathered at different locations on the island was assessed by counting and identifying the fungal colonies growing out on different agar media, containing various amounts of soil extract.

The following fungi were isolated: Absidia corymbifera (Cohn) Sacc. \& Trott, Cladosporium macrocarpum Preuss, Epicoccum purpurascens Ehrenb. ex Schlecht, Mucor hiemalis Wehmer $(+)$, Penicillium palitans Westling, Phialophora fastigiata (Lagerb., Lundberg \& Melin) Conant, P. malorum (Kidd \& Beaum.) McColl, Trichoderma harzianum Rifai, T. viride Pers.: S. F. Gray, Ulocladium botrytis (Preuss) Simmons, and Verticillium psalliotae Treschow. Most of the fungal propagules occurred only sparsely ( $<50$ per g soil), and from some of the soil samples no fungi were isolated. At the samplings, soil temperatures were in the range of $12^{\circ}$ to $45^{\circ} \mathrm{C}$ and isolation plates were incubated at $25^{\circ} \mathrm{C}$. Absidia corymbifera is thermotolerant but none of the isolated species is known to be thermophilic. The fungi isolated are all common terrestrial species.

In the summer of 1976 , the first specimens of a hymenomycete, identified as Omphalina cf. trigonospora Lamoure, were observed. They were first found in a moist cave but later, in 1981, were found together with mosses growing along the outer rim of the crater of Surtur II close to fumarols.

The fungi mentioned have probably immigrated to Surtsey by air, but fungal propagules may also have been transported by sea and by sea-birds, which frequently visit the island for temporary resting and more rarely for nesting. Fungi may also inadvertently have been dispersed to Surtsey by man.

\section{Acknowledgments}

Dr J. A. von Arx, Baarn, The Netherlands, and Professor D. Lamoure, Lyon, France, are gratefully acknowledged for collaboration.

\section{References}

Henriksson, L. E. \& Henriksson, E. 1974. Occurrence of fungi on the volcanic island of Surtsey, Iceland. Acta Botanica Islandica 3, 82-88.

- \& 1982. The biological succession on the new volcanic island Surtsey, Iceland, with special reference to the biological fixation. Transactions of the 12th International Congress of Soil Science, New Delhi, India, 8-16 February 1982. Voluntary papers, Abstract, 56-57. 